\title{
ART DECO IN ESTONIAN AND LATVIAN GRAPHIC DESIGN JOURNALS
}

\section{Merle Talvik}

\begin{abstract}
Years of the first independence in Estonia and Latvia involved the second wave of nationalism in art and culture. National theme became a source which had to be treated fashionably. The fashionable European style was art deco that spread in the Baltics, Finland and elsewhere in periphery of Europe from the second half of the 1920s until 1940. The author has examined and analysed a wide variety of Estonian illustrated magazines and journals. The examples of Latvian magazines come from the collections of the Information Centre of Art Academy of Latvia.

The article explores common features in the pieces of the following artists: Vabbe - Vidbergs, Vaino - Apsītis, Madernieks - Reindorff, also Luhtein, Siirak, Mugasto, Verny, Triik versus Strunke, Zeberin̦š and Kasparsons.

The first goal is to prove that graphic design journals in art deco style were very popular in the periphery of Europe in these years. Secondly, the author claims that objects that apparently lie outside the definition of 'art' can be subjected to visual analysis in such a way as to open important doors to the understanding of their origin, reception, place in society, and subsequent history. They are reflections of relations of power, aesthetic objectives, changing theories and rituals of art and society. This is the reason why graphic design journals are treated as carriers of culture.
\end{abstract}

Keywords: graphic design journals, applied graphics, Estonian and Latvian art, visual culture, silent age

\section{INTRODUCTION}

Journalism gives good information to historians about the lifestyle and cultural standard of an era. Not only the text but also an appearance of a journal (cover design, illustrations, vignettes, etc.) contain a lot of information.

Graphic design journals and magazines have beenpublished in Europe, the USA and other countries since the 19th century. The journals covered graphic design, typography, illustration, advertising, photography, book publishing and other related subjects such as the mechanical aspects of publishing. Many of these journals demonstrate beautiful graphics and are an excellent source of information about the artists as well as about the everyday life of people. It 
is important that they include a far wider range of visual materials than is normally embraced by art history. They are reflections of relations of power, aesthetic objectives, changing theories of art and even the religious conceptions and rituals of society.

In the pre-television era, written press was intended for a very wide audience. As almost the only channel of mass media, it had an immense influence on shaping people's tastes and preferences, thus guiding the political arrangement and cultural life of society. Media was also a tool for exercising power thanks to the rather privileged access of politicians and government officials to journals and magazines.

From the point of view of culture, media is the primary source for defining social reality and the most widespread expression of the collective identity or Zeitgeist.

The German word Zeitgeist means the spirit of time and refers to the cultural trends and tastes that characterise a given era. The field of graphic design on the whole is characterised by immediacy and a short life-span, on which P. B. Meggs (1998: xiii) and M. Rickards (1988: 13) have focussed in their research. Thus journals are passing documents of everyday life, the contents of which are often not meant to last longer than a week or a month. A typical person throws them out after reading. The journal is always directed to the contemporary consumer, it reaches almost everyone in the society. From this stems the link between its contents and the vision of the social, political and economic life of the society that often enables it to express the Zeitgeist of the era more closely, by telling more than other means of human expression, such as the art of painting. We see and read the human story in journals.

The years of prewar national independence (1918-1940) in Estonian and Latvian art are characterised by a national-inspired approach to form and decoration. Development took place in parallel in both countries, as cultural contacts were close. In the first part of the present article the author provides an overview of the development of the national style in Estonia, to the study of which the author has dedicated 7 years. The best studies of Latvian artistic developments in the first half ot the 20th century are written by M. Brancis (1994), S. Grosa (1999) and J. Howard (2004). But they mainly 
concentrate on jugendstil or art nouveau, and do not explore the era of art deco. That is why in the present article the author takes one step forward and looks at the works in the style of art deco, trying to assess their artistic maturity in the cultural context.

The era of art deco in Estonian and Latvian graphic design journals can conventionally be divided into two. The best works in the art deco style are from the second half of the 1920s and the beginning of the 1930s, when preconditions for the development of journalism were good and the freedom of activity was great. On the basis of the works of the second half of the 1930s, both in Estonia and Latvia, a consequent direction of state national propaganda through art into public consciousness can be observed. The cover picture is no longer a work of "art for art's sake". It has been given the high-minded objectives of shaping a citizen who thinks independently and is selfaware, which, ultimately, should have improved the culture and quality of life of the whole society. The individual contribution of the artist was subjected to function, the ideological basis of which was the futuristic belief in a better tomorrow, the method for which was proto-totalitarianism.

\section{THE DEVELOPMENT OF NATIONAL GRAPHIC DESIGN IN ESTONIAN WRITTEN PRESS}

National independence brought along an increase in the number of publications. In the years of prewar national independence (19181940) over 200 journals and bulletins were published in Estonia, 90 per cent of them were in Estonian. Most of them had an artistic look with remarkable decoration and composition, texture, colouring and script drawn by well-known artists. Both the content and appearance of the journals were shaped by local economic and cultural conditions.

The keywords for art between the two world wars were order, monumentalism, nationalism, classics and hierarchy, which were especially clearly expressed in architecture (Borsi 1987: 13; Kalm 1990: 75-100; Kalm 1994: 93-136; Kodres 2001: 236-240). The young Estonian national culture, with its identity to protect, had taken the direction of internationalism via nationalism. In a few decades Estonian culture developed extremely fast. In 1968 B. Bernstein 
introduced the relatively new term of "national culture accelerated development" in the Estonian art history. A few years later B. Bernstein wrote the following

The essence of accelerated development lies in the fact that the culture of a given ethnic union makes up for what it has missed by relying on foreign experience and acquiring it in its own way. Unions possessing this cultural experience may have moved ahead in one, two or three phases; in this case accelerated development does not quickly repeat all the phases in-between but it skips them" (Bernstein 1977: 27).

This fact inevitably posed Estonian artists the problem of creative copying and interpretation. In a short time a synthesis of the national tradition, which is difficult to define, and the international cultural experience treated as a certain "norm" had to be achieved (Abel 1995: 143).

The basis for the development and spread of graphic design in the 1920s and 30s was the rapid development of the economy and commerce in the country. The rise in the number of publications led to a greater need for designers. The need for local staff arose in all fields of applied graphics. The rise began with the development of graphic art currency design and badge design, leading to the founding of numerous new enterprises and organisations that in the conditions of economic competition created favourable grounds for advertising. As the demand in applied graphics grew, many visual artists like Nikolai Triik, Ado Vabbe and Günther Reindorff were active in this field. Most of them had received their education and first artistic experiences in St. Petersburg or Western Europe. Many applied graphic artists were self-taught.

In the 1920 s and especially in the $30 \mathrm{~s}$, applied artists and graphic artists trained in decorative painting or graphic art at Riigi Kunsttööstuskool (State School of Applied Art) in Tallinn and visual artists who had studied at Kõrgem Kunstikool Pallas (Higher Art School Pallas) in Tartu also became active.

Tallinn school can be characterised by a masterly script, refined stylising of ornament in art deco style, integral composition and 
essentially motivated use of pictorial images. Script, ornament and drawing are logically connected, forming a compact and rich whole. National ornament is widely used. The mission of creating distinctive national style emerged in the foreground. The curricula of the State School of Applied Art were modelled upon those of the Stieglitz Institute of Technical Drawing in St. Petersburg which focussed on applied art. The study conditions at the Stieglitz Institute were more appropriate for ordinary people than other art education establishments in St. Petersburg and many young people from the Baltics acquired their education there, including about 60 Estonians. The curricula of the Tartu Higher Art School were based on Western European art experience. Therefore the visual language of the artists from Tartu school is more picturesque. Individualities emerge more clearly. National propaganda is less evident, but script is often unprofessional.

The so called "silent age" in Estonian politics (1934-1940) involved a second wave of nationalism in Estonian art. National theme in ornament and images became a source that had to be treated fashionably. Motifs and colours were taken from folk embroidery. Ornament was geometrised in the style of art deco and connected more or less harmoniously with script. Geometric division of surfaces was widely used.

\section{COMPARISON OF ESTONIAN AND LATVIAN GRAPHIC DESIGN JOURNALS}

Unabashed novelty, chic modernity and constant change all played a part in the creation of the myriad of styles, looks, products and ideas which characterize the 1920s and 1930s (Horsham 1997: 11). Jazz music, the spread of wireless communications, skyscrapers, subways, orientation to mass production, the emergence of advertising art, great tolerance towards other experimental art movements and the transfer of all this to national socialism, antisemitism, the empires of Adolf Hitler and Josef Stalin all belong to two decades.

Reoccurring shapes, contrastive lines expressing speed, bright primary colours, the flatness of the picture surface, stylising and geometric simplicity made modernist art and its way of thinking un- 
derstandable and accessible for everyone. Mass production did not necessarily have to mean a reduction in quality (Sternau 1997: 36).

The interest in indigenous and national art was very characteristic of the art deco era. As we know, no "pictures" were featured in Estonian and Latvian national art, but ornament was. In graphic design one cannot do without the figure and that is why the national human figure was introduced, which besides journals is also featured on several diplomas and certificates and can easily be recognised by adding national costumes or some other national symbols (Talvik 2000: 36). It is an impersonal figure with a typical face, mostly a female, with whom it is easy to identify. This angular, strong female is a completely different person from the shy woman of the Jugend era. She either does cross-stitch, sings or defends the country, she is self-conscious, demanding an equal position with men in the life of society. This woman is thoroughly national but also entirely art deco. A typical art deco woman has freed herself from the confines of bustles and corsets, her silhouette is tall, tubular and unadorned, she has bobbed hair, she wears a cloche hat (see Fig. 1) and a shortish dress, drives a car, drinks alcohol and smokes equally with men. We see a woman like this in the drawings of the fashion genius Paul Poiret, and also in the drawings of George Lepape for the journal Vogue and in Vladimir Bobritsky's drawings for the journal Vanity Fair. The woman is often accompanied by hounds or deer with streamlined bodies, as symbols of speed and modernism. So did Estonian and Latvian artists produce many images of the modern woman living the good life. The fashionable woman of leisure appears on a cover to Atpūhta (Vacation) No 360,1932. It is an aquarelle of Aleksandrs Apsītis (1880-1942) called Near the Opera. The beautiful and gracious lady is pictured walking a dog in an autumnal park in front of an opera theatre. In the background other strollers can be seen and a car as the symbol of a comfortable lifestyle. The composition is complete, the colouring tasteful and soft (see Fig. 2). Aleksandrs Apsitis was an original artist, who did not have a good education. But he was a skilful drawer who created his own ideal of beauty in journalism oriented to a wider audience. He regularly published his drawings in journals Jauna Nedęla (Young Week), Atpūhta (Vacation), Ilustrēts Žurnāls (Illustrated Journal), Zeltene (Maiden), Latvijas Jaunante (Youth of Latvia) and Tautas Žurnāls Visiem (Popular Journal for Everybody). 
We find the same scene on the cover of the Estonian journal Kodu (Home). Estonian graphic artist and painter Eugen Vaino (19091969) was a member of the State Applied Art School generation. In the 1930s he was active in the fields of graphic art and applied and book graphics. On the cover of the journal Kodu issue no. 8 from 1937 he depicts in an art deco manner a couple with stretched figures walking a dog. The motif is a typical one, but the figures are flat and superficial. The composition as a whole is not convincing and the work is obviously not as good as that of the classics of the world (see Fig. 3). It is more of a decorative than artistic composition that again makes it possible to identify with the figures represented, as though everyone could afford to have a walk like that. This represents an identity, a feeling of belonging among happy and satisfied people. Art deco graphic artists create a world of escapism (Sternau 1997: 69) by representing something to be wished for, desired, a splendid world of fantasy, not reality. Hence the snobbery and glamour that are characteristic of the style.

Often we see happy couples spending time in the country or in the amusement park. Reinholds Kasparsons (1889-1966) worked for many years at the Atpūhta, where he was active in the field of applied graphics. He also made posters and painted porcelain. His scenes of vacation on the covers of Atpühta can be compared to the cover drawings of the American journal Woman's Home Companion, which spread in Estonia and probably in Latvia too. Indrikis Zeberinsš (1882-1969) also worked intensively for journals, he published his first drawing in the journal Vērotajs (Observer) in 1905. He liked to depict patriarchal peasant life. On the covers of Atpūhta he deviates from his favourite characters, peasants, by depicting town people having a holiday in the country. These cover drawings do not carry specific formal features of art deco, but depict the lifestyle of the era.

Among the Estonian artists, Nikolai Triik (1884-1940) undoubtedly had as much experience in illustrating journals, attracting attention in 1905 with his romantic "Tulekandja" (Flame Bearer) on the cover of the Noor-Eesti (Young Estonia) I album. N. Triik had been educated at the St. Petersburg Stieglitz Institute, and complemented his skills at the liberal Paris academies. From 1921 he was a tutor in Pallas, and for a short time also the director. In the 1930s N. Triik 


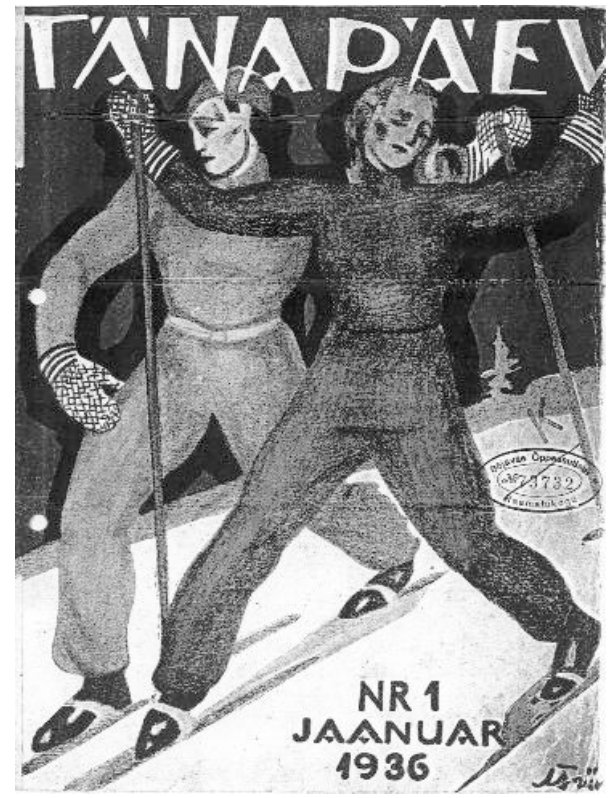

Figure 4. Nikolai Triik. Magazine cover. Tänapäev (The Present Time), January, 1936.

was closely linked to the Tartu journals Tänapäev (The Present Time) and Olion (Was-Is). The 1936 January issue of Tänapäev features his pencil drawing in colour, called "Suusatajad" (The Skiers). The theme is characteristic of the art deco era, the drawing is generalised (see Fig. 4). The cover drawing of the 1927 Atpūhta issue no. 163 by the Latvian grand master Sigismunds Vidbergs (1890-1970) depicting skaters is similar (see Fig. 5). S. Vidbergs was one of the truly original and versatile Latvian artists. He is mostly known as a wonderful graphic artist and book illustrator, but he also designed textiles and stained glass, painted porcelain, and worked as a theatre set designer and an art teacher. He graduated from the Stieglitz Institute in 1915, edited the satire journal Ho-Ho, and was head of the art department of the Ilustrēts Žurnāls (Illustrated Journal). He started in Jugendstyle, but changed his style into art deco in the second half of the $1920 \mathrm{~s}$. He uses ornamental surfaces, and his drawing is decorative, salon-like, elegant, the influence of the ori- 


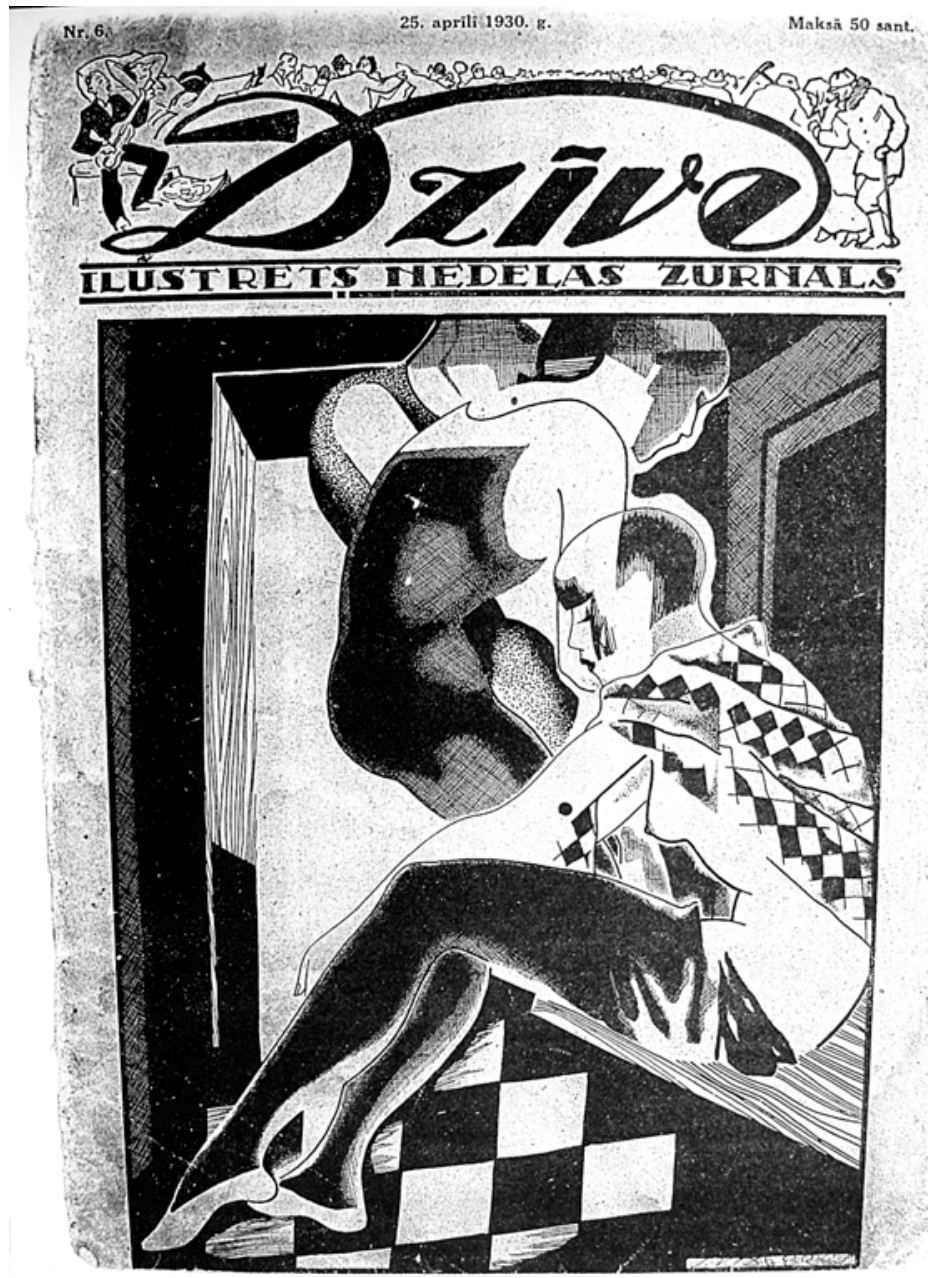

Figure 6. Sigismunds Vidbergs. Magazine cover. Dzive (Life), no 6, 1930.

ent and erotic taste being noticeable. Coquettish ladies, harlequins, ballroom, café and beach scenes are S. Vidbergs' favourite themes on the covers of the journals Dzīve (Life, see Fig. 6), Eleganta Rīga (Elegant Riga), Atpūhta (Vacation), Jaunā Nedēḷa (Young Week), and on illustrations and vignettes. 
The airy elegance of S. Vidbergs' drawings in Chinese ink can to a certain extent be compared to the style of Estonian Ado Vabbe (18921961). Ado Vabbe studied in Munich 1911-1913 at the art school of A. Ažbé. For 21 years between 1919 and 1940 he worked in Tartu at the Pallas as a tutor of painting and graphic art. Having encountered new art movements in Munich, he became a keen disciple of them. In his earlier drawings a Jugend stylisation prevails. A. Vabbe was associated with the traditions of the Noor-Eesti (Young Estonia) movement, A. Beardsley, and the art world of Mir Iskusstva (Solomykova 1972: 25). A. Vabbe shaped his improvising objectless manner of drawing on the style of Vassili Kandinsky, whom Ado Vabbe knew personally (Paris 1939: 653; Hain 1992: 141; Komissarov 1992: 7; Varblane 1994: 183), and on the influence of the abstract expressionism of the group Der Blauer Reiter. Like V. Kandinsky's, A. Vabbe's drawing is a synthesis of what he depicted and what the depicted subject could imply. He also became acquainted with the creative work of the futurists, but aggressive and destructive methods did not suit A. Vabbe. He liked the futurists' way of structuring the surface, dividing the picture surface into mosaic pieces, and also the transfer of the movement effect. But he always remained an aesthete; balance, elegance and beauty prevail in his works (Varblane 1994: 185). In this sense Ado Vabbe may certainly be compared to Sigismunds Vidbergs. His love for masquerade-like and theatrical scenes also brings A. Vabbe nearer to S. Vidbergs.

Issue no. 6 of the 1939 Varamu (Treasury) presents reproductions of Ado Vabbe's work and is illustrated with his vignettes. The drawing by Ado Vabbe at the end of the article has special impact (see Fig. 7). All three, the goat, the tiger and the fragmentally depicted person, are walking in the same direction, but there is no contact between them. This is actually the main attitude of the figure compositions of A. Vabbe - each figure has frozen into its own hermetic existence (Lamp 1976). All his popular harlequins and the characters of many illustrations are like this. The characters of Sigismunds Vidbergs sometimes also either look over or past one another (see Fig. 6) and sometimes the figures are only drawn with a few single lines. Like A. Vabbe, S. Vidbergs also finds letter combinations that match the style of drawings but is not capable of any more in the field of calligraphy. 


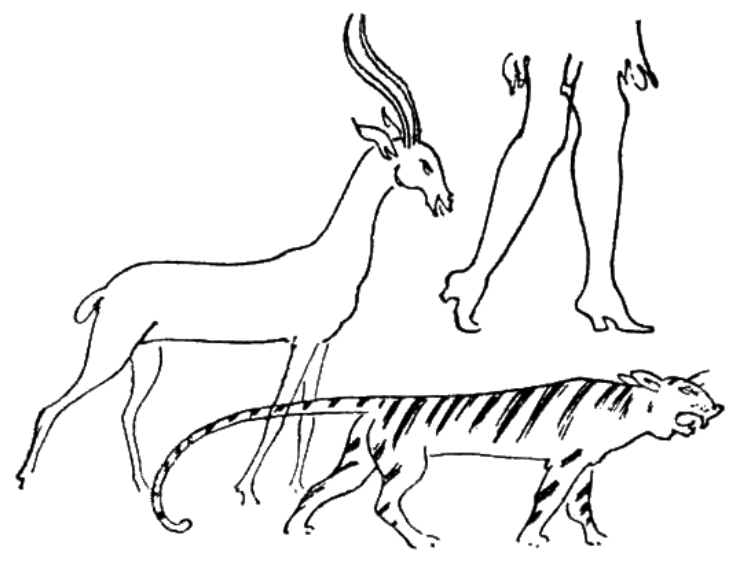

Figure 7. Ado Vabbe. Vignette to Varamu (Treasury), no 6, 1939.

Hando Mugasto (1907-1937) was the most talented of the Tartu artists as a calligrapher. He studied at Pallas, tutored by Eduard Wiiralt and Ado Vabbe. The journal Teater Vanemuine (Theatre Vanemuine) was published in 1935-1938 with H. Mugasto's cover design (see Fig. 8). This was the finest example of the application of art deco methods the design of Estonian journals. The design is characterised by a constructivist surface and art deco script. Another example of such pure style is the cover by Jaan Siirak (1897-1959) for the January issue of the 1935 Teater (Theatre) (see Fig. 9). Between 1924 and 1932 internal design architect and furniture designer Jaan Siirak lived in the art deco capital Paris, where he was active in the field of fashion and studied at the École des BeauxArts.

Sometimes the scenes on the covers of journals are flavoured with humour. The Tallinn artist Verny, actually Werner Birkenfeldt (19031942) mostly worked for newspapers but also for journals. Verny became a very productive drawer in the entertainment genre in the 1930s. His illustrative, sometimes stereotypical style is characterised by technical skill and mellow humour. No less humorous and sweet are the scenes of Aleksandrs Apsitis on the covers of Atpūhta, 1930. 


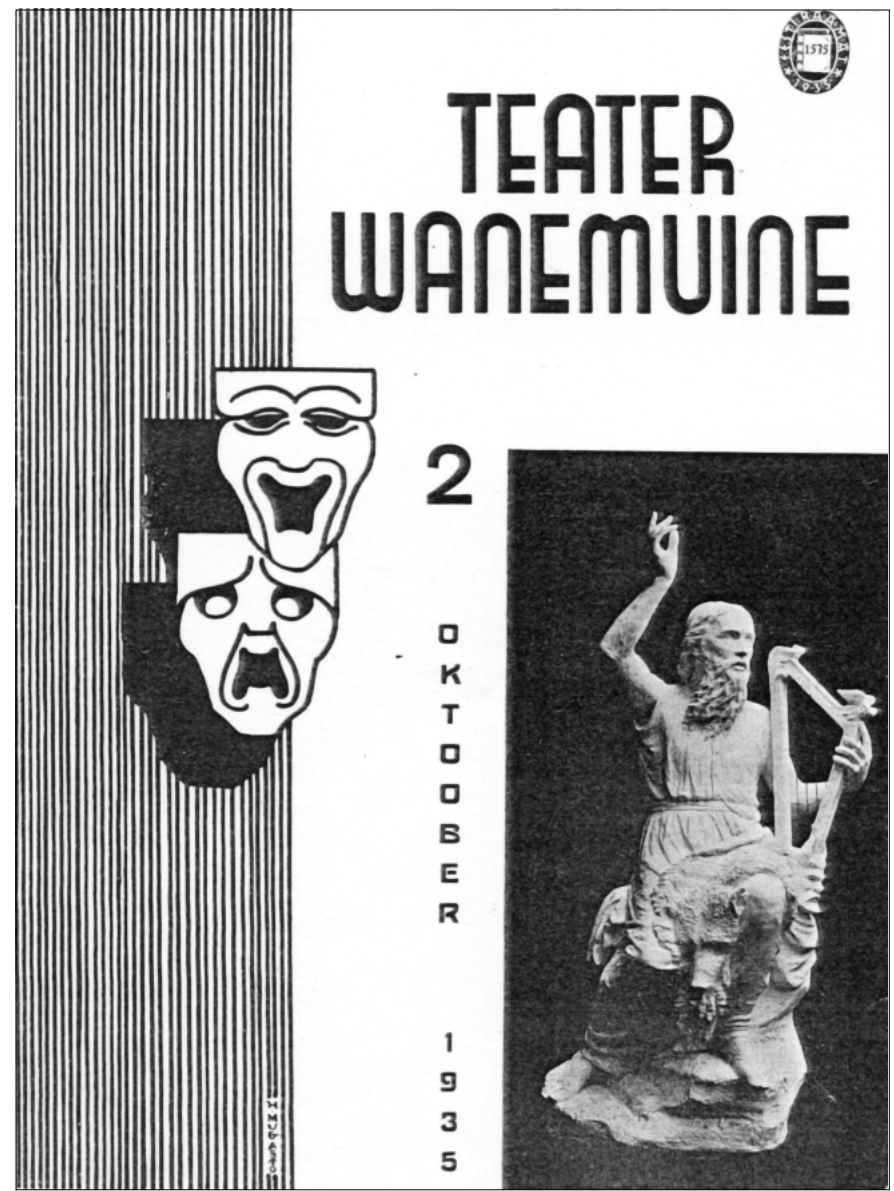

Figure 8. Hando Mugasto. Magazine cover. Teater Vanemuine (Theatre Vanemuine), no 2, 1935. 


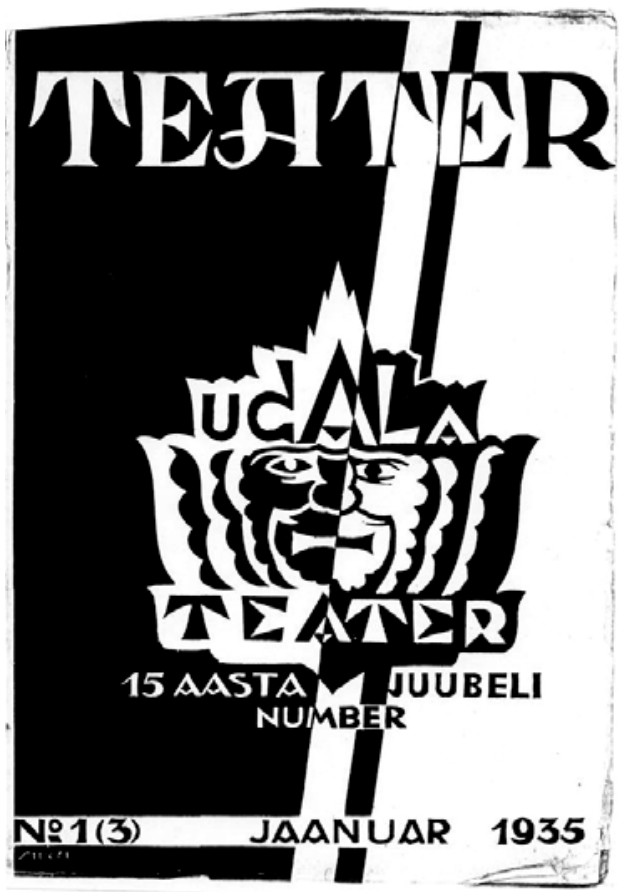

Figure 9. Jaan Siirak. Magazine cover. Teater (Theatre), no 1, 1935.

These sweet pictures are understandable for everyone. It is important that the cover picture is essentially an advertisement, it advertises the journal and together with it a certain lifestyle. The advertisement always has a message with a certain objective to forward to a certain audience. The target group, of course, is the people who have enough money to consume. The message must be understood, and in an unambiguous way. Clarity is one of the biggest virtues of advertising. That is why advertisements are often shallow and trivial. An advertisement is not a place for philosophical musings. The objective is to create a positive image. Aesthetic values are thus important, the rules of politeness must not be broken. 
Obviously, an ugly picture "does not sell". Positivity is an important keyword in the journals of the 1930s in two ways. Firstly, compulsory positive associations in advertising and secondly, positivity in the nationalism sense, a positive attitude towards the state and the government which the journals propagated. This cult of the diligent citizen, as it was called, directly echoed the national united nation programme, which presaged the focus on the positive. According to M. Peil (1989), the content in the journals of the time was "Ordered to be positive, tendentiously progressive, and decent and abstinent", and we sense the same in design. The fact that during what was called the silent era, 1934-1940, journalism was after-censored, is of importance too. Thus there was the danger that by using only external tools in aspiring for positive nationalism, artists could be inclined towards "formal-national" art and lose their artistic way of expression. There were cases when the careful coif-and-belt ornaments could not disguise the lack of character of the work of art. Thus the author believes the use of the term proto-totalitarianism is justified in the case of some works of the graphic design journals in the second half of the 1930s.

Speaking of works built on ornament, it is appropriate to speak of two artists, who used ornament in an artistic way, creating integral compositions with it. They were Latvian Jūlijs Madernieks (18701955) and Estonian Günther Reindorff (1889-1974), both students of the Stieglitz Institute, who later trained in Europe with scholarships of the institute. J. Madernieks was a master of Latvian ornament, the founder of professional applied art. At first his style was influenced by Jugend, later he developed his own characteristic style. He united elements of free improvisation and borrowed forms with geometrical ornament. The block of colours (blue, red, brown and grey) show a free association with folk embroidery. He changes folkloric material into a powerful heroic image, as we can see on the cover to Sievietes Pasaule (Woman's World) issue no 23, 1935. Script is also intertwined with ornament, organically growing out of it (Fig. 10).

G. Reindorff, who in the 1920s and 1930s mostly worked as an applied graphic artist, was employed by the Estonian State Printing Plant (Riigi Trükikoda) as a consultant artist and also contributed to different advertising agencies. Influenced by the aesthetics of 
Figure 1. Niklavs Strunke. Magazine cover. Atpūhta (Vacation), no 208, 1928.

Figure 2. Near the Opera. Magazine cover of Aleksandrs Apsītis. Atpūhta(Vacation), no $360,1932$.
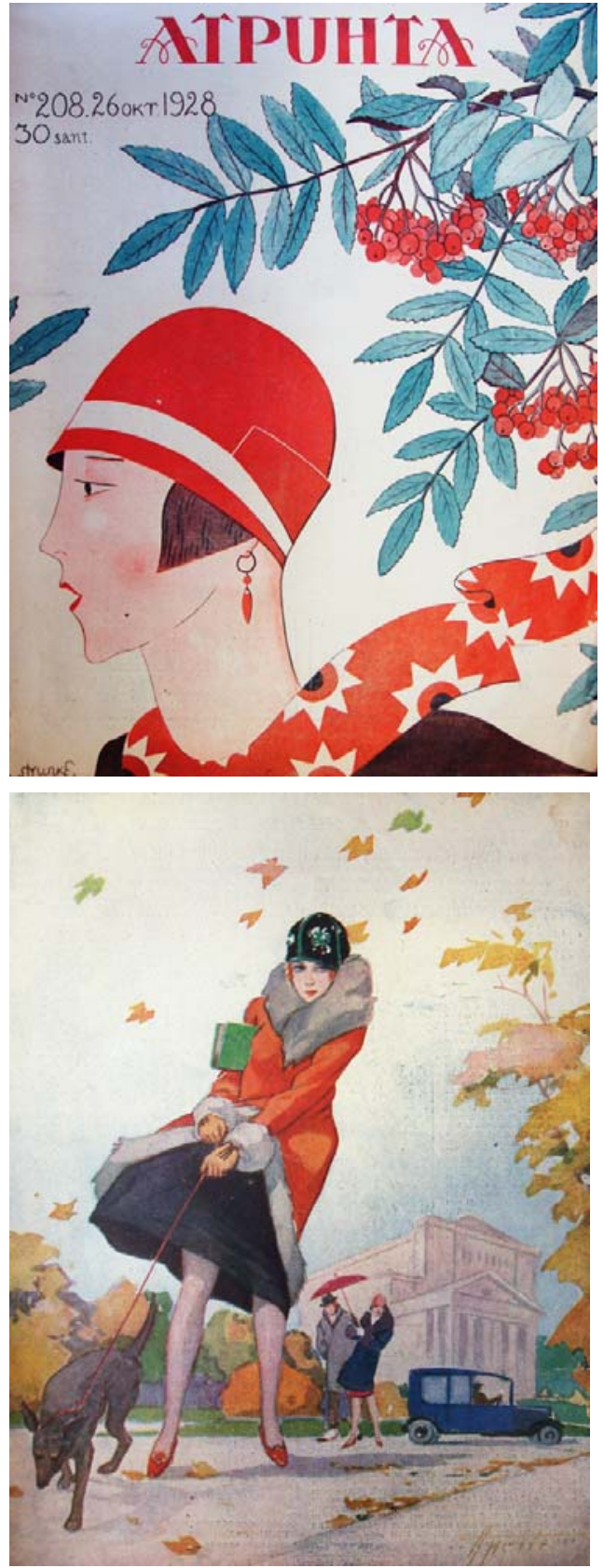

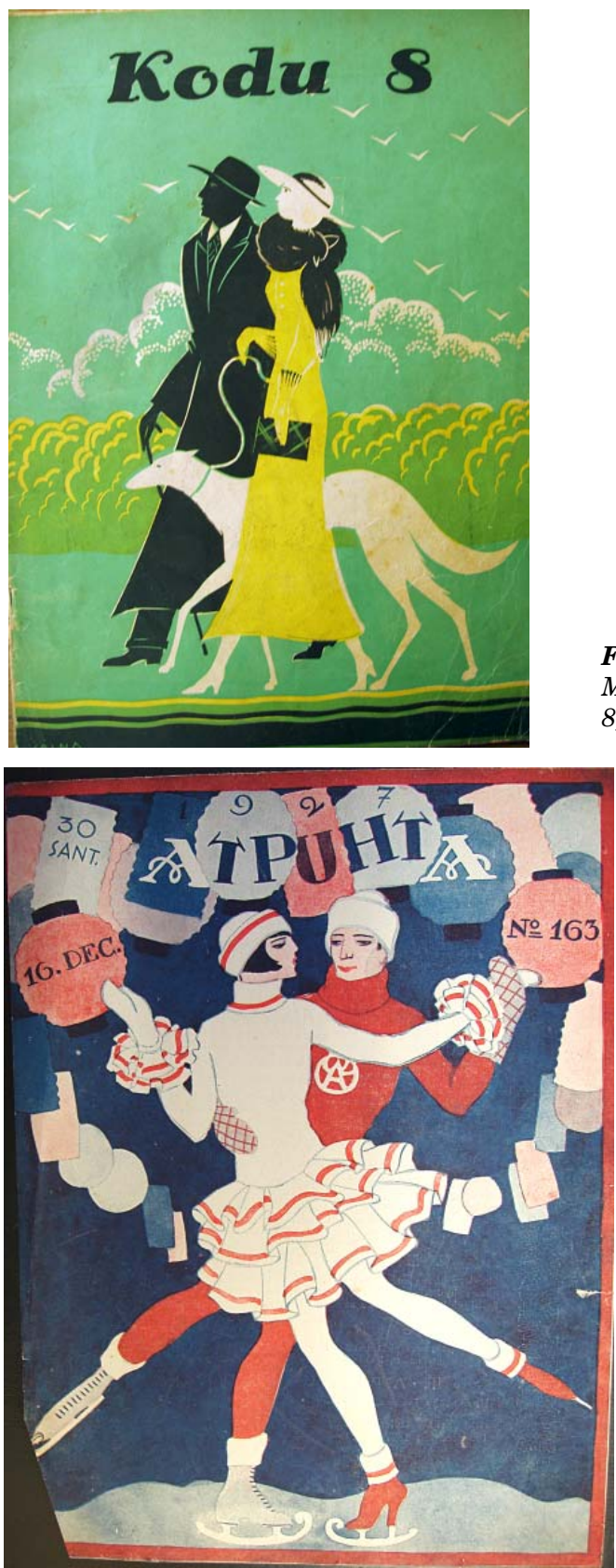

Figure 3. Eugen Vaino.

Magazine cover. Kodu (Home), no 8, 1937.
Figure 5. Sigismunds

Vidbergs. Magazine cover.

Atpūhta (Vacation), no 163, 1927. 
Figure 10. Jūlijs Madernieks. Magazine cover. Sievietes Pasaule (Woman's World), no $1,1932$.
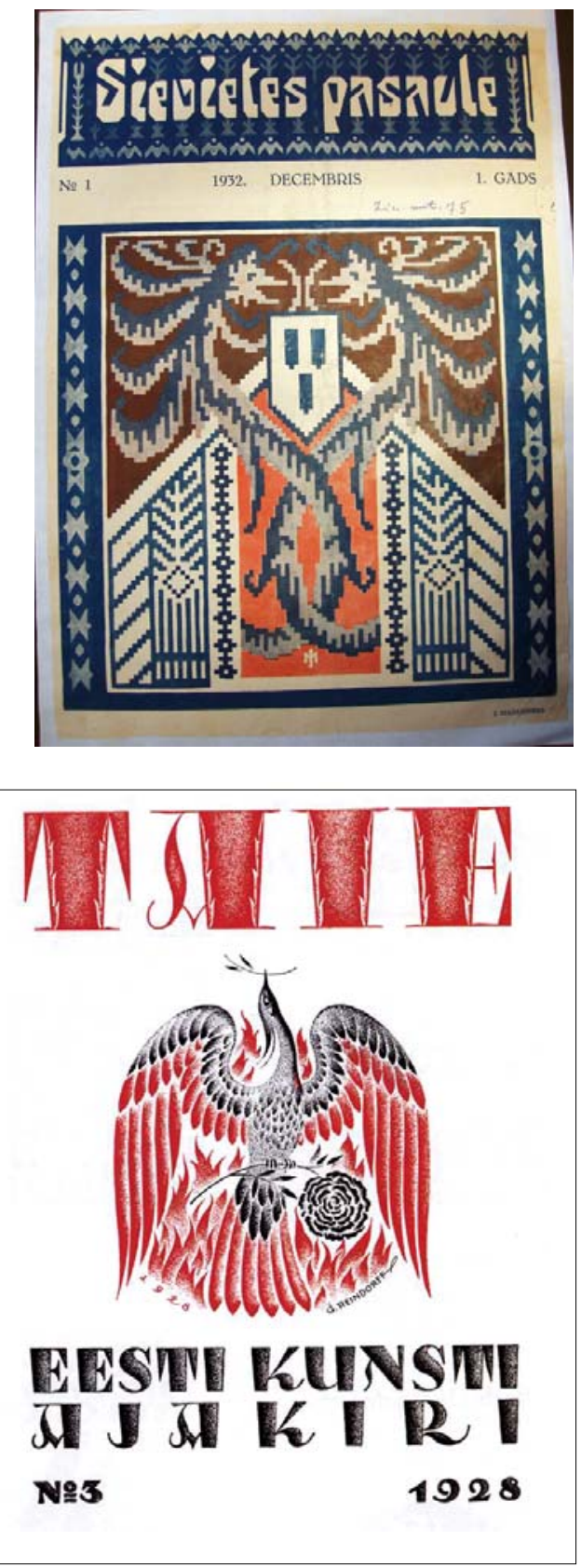

Figure 11. Günther

Reindorff. Magazine cover.

Taie (Art), no 3, 1928. 


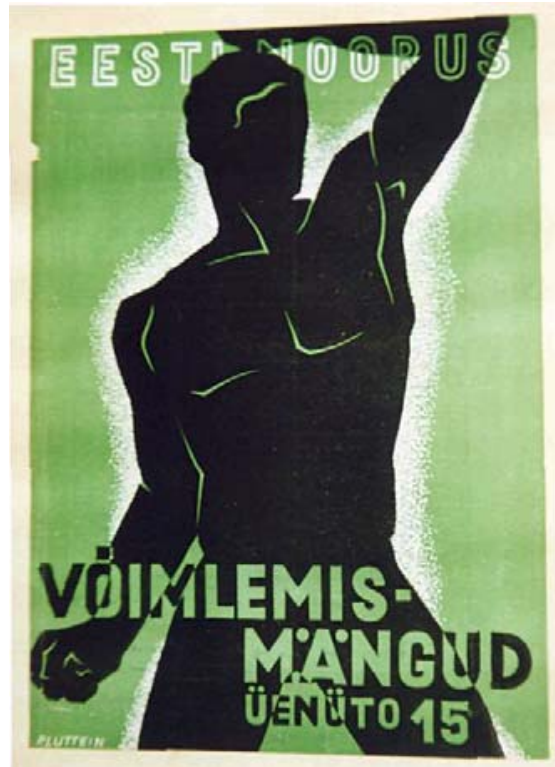

Figure 12. Paul Luhtein. Magazine cover. Eesti Noorus (Estonian Youth), special issue, 1934 .

the Russian group Mir Iskusstva (World of Art), he introduced artistry, the beauty of lines and shapes, into graphic design. His style is characterised by the classical elegance of stylised ornament and decorative elements. The ornament is festive and gracious. An illustrative tendency dominates over the strict or logical structure of the script. The sharp contrasts of the different parts of the letter create a dynamic impression.

The cover by G. Reindorff to the journal Taie (Art) from 1928 (see Fig. 11) has become the classic of Estonian graphic design, on which, together with the gracious phoenix, we see the ornamented script created by Günther Reindorff, with its principal lines narrowing towards the bottom. This script served as an example to a whole generation of Estonian applied graphic artists, including the expert calligraphers Paul Luhtein and Johann Naha. During the years 
1936-1940 the journal Muusikaleht (Journal of Music) was published with the elegant integral design by G. Reindorff with a heading in italics and an art deco ornament decoration.

Paul Luhtein (born 1909), a student of Günther Reindorff, is a very good stylist. His style was determined by two controversial methods. The decorative, ornamental manner acquired at the State School of Applied Art was complemented by the simplicity, the soberness of compositional solutions and functionalism, and the aspiration for integrity learned at Leipzig Academy of Graphic and Book Art (Loodus 1980: 6). His creative output is vast and many-sided. On the covers of the journals Välis-Eesti Almanak (Foreign-Estonian Almanac; 1931-1934), Sõdur (Soldier; 1931-1934) and Postisarv (Post Horn; 1937-1940) functionally divided picture space, poster-like usage of colour and a clearly readable Roman script can be found. On the cover of the sport-themed special issue of the Eesti Noorus (Estonian Youth) (1934) we see a typical male figure. In this case we are not dealing with a self-satisfied, smoking, candy-eating consumer, as abundantly portrayed in the advertisement graphic art of Estonia and other countries, but a male nude (see Fig. 12). An art deco male nude in graphic design is stylised and monumental, classical but at the same time dramatically modern. The functional Roman script supports the figure.

J. Madernieks, G. Reindorff and P. Luhtein were artists who had respect for both national art and modern movements of art, while at the same time preserving their character and creative brilliance.

\section{CONCLUSION}

On the preceding pages the author has provided an overview of Estonian and Latvian graphic design journals during the art deco era. This was the era when the issue of nationalism became the focal point in all spheres of life. Independence had been achieved, people had become Europeans, and now, a certain contra-movement, which required the re-honouring of the indigenous culture and its usage in modern art, occurred as a protest. The national inferiority complex was overcome and people were again feeling proud of the strength of their culture. 
But the aspiration for identity always requires both identification and differentiation: on the one hand the European culture, the following of fashion movements; on the other hand the security that was offered by the collective creation of the nation, ornaments that were considered as a national inheritance, combinations of form and colour. In the 1930s the influence of totalitarian regimes deepened in European countries including periphery and there was an inclination towards traditionalism in culture. Both, in Estonian and Latvian culture, the so-called silent era also brought out a submissive attitude. Here again two forces could collide - on the one hand the whole, forced to be homogeneous, a national or social great idea that required personal submission, on the other hand a liberal artist, individualism and democracy.

Actually, it is not always possible to differentiate what is our own and what is foreign, because the different influences are so intertwined and styles of art are always international. Both Estonia and Latvia were open to the outside world in the 1930s and last of all our national ornamental art mostly stems from the treasuries of Baroque art.

\section{References}

Abel, Tiina 1995. "Pallase" koolkonnast 1930. aastate kunstiprotsesside foonil (Sissejuhatus koolkonna loomingu käsitlusse) [About the "Pallas" school on the background of the 1930s art processes (An introduction to treating the school's works)]. Sarapik, Virve et al. (eds). Kunstiteaduslikke uurimusi $=$ Studies on art and architecture $=$ Studien für Kunstwissenschaft, 8. Tallinn: Eesti Kunstiteadlaste Ühing, pp. 143-166.

Bernstein, Boriss 1977. Kunsti rahvuslikust omapärast [On the national uniqueness of art]. Lumiste, Mai (ed.). Töid kunstiteaduse ja kriitika alalt, 2: Artiklite kogumik. Tallinn: Kunst, pp. 13-29.

Borsi, Franco 1987. The Monumental Era. European Architecture and Design, 1929-1939. New York: Rizzoli.

Brancis, Māri. 1994. Jūgendstila ornamentika Latvijas žurnālos 19. gs. beigās un 20. gs. sākuma [Jugendstil ornaments in Latvian magazines at the end of the 19th and the beginning of the 20th century]. Grosmane, Elita (ed.). Ornaments Latvijā: Materiāli mākslas vēsturei. Riga: Zinātne.

Grosa, Silvija (ed.) 1999. Jugend stils: Laiks un telpa: Baltijas juras valstis 19.-20.gs. mija = Art Noveau: Time and Space: The Baltic Sea Countries at the Turn of the 20th Century. Riga: Jumava. 
Hain, Jüri 1992. Mees, kes tahtis tulla Tartu [The man who wanted to come to Tartu]. Looming, 1, pp. 139-141.

Horsham, Michael 1997. '20s and '30s Style. London: Quantum Books.

Howard, Jeremy 2004. From the Stieglitz Forward: The Snaking Progress of Latvian Applied Art ca. 1900-1914. Centropa: A Journal of European Archtecture and Related Arts, 4 (3), pp. 267-280.

Kalm, Mart 1990. Riigi esiarhitekt Alar Kotli [The national grand architect Alar Kotli]. Kotshenovski, Oleg (ed.). Linnaehitus ja arhitektuur = Gradostroitelstvo $i$ arkhitektura. Tallinn: Ehituse Teadusliku Uurimise Instituut, pp. 75-100.

Kalm, Mart 1994. Arhitekt Alar Kotli [The architect Alar Kotli]. Tallinn: Kunst.

Kodres, Krista 2001. Ilus maja, kaunis ruum: Kujundusstiile VanaEgiptusest tänapäevani [Beautiful house, nice room: Decoration styles from Old Egypt to today]. Tallinn: Prisma Prindi Kirjastus.

Komissarov, Eha 1992. Vabbe - helesinine ratsanik [Vabbe - a blue rider]. Kunst: Art in Estonia, 3, pp. 7-9.

Lamp, Ene 1976. Ado Vabbe ja moodne kunst [Ado Vabbe and modern art]. Sirp ja Vasar, May 22 \& 28.

Loodus, Rein 1980. Paul Luhtein ja tema looming [Paul Luhtein and his creative works]. Tallinn: Eesti Raamat.

Meggs, Philip B. 1998. A History of Graphic Design. 3rd Edition. New York: John Wiley \& Sons.

Menten, Theodore 1975. Advertising Art in the Art Deco Style. New York: Dover Publications.

Paris, Rudolf Johannes 1939. Ado Vabbe. Varamu, 6, pp. 647-658.

Peil, Mirjam 1989. Eesti naisteajakirjadest, seekord "Taluperenaisest" [About Estonian women's journals, thise time about "Taluperenaine"]. Reede, 38, September 22, p. 8.

Rickards, Maurice 1988. Collecting Printed Ephemera. New York: Abbeville Press.

Solomõkova, Irina 1972. Ado Vabbe varasemast graafikast [About the earlier graphics of Ado Vabbe]. Kunst $=$ Art in Estonia, 42 (2). Tallinn: Kunst, pp. 23-27.

Sternau, Susan A. 1997. Art Deco: Flights of Artistic Fancy. New York: Smithmark Publishers.

Talvik, Merle 2000. Mõningaid näiteid Eesti 1930-ndate aastate diplomite ja tunnistuste kujundusest [Some examples from the design of diplomas and sertificates from the 1930s Estonia]. Tuna: Ajalookultuuri Ajakiri, 3, pp. 30-36.

Varblane, Reet 1994. Ado Vabbe ja moodne kunst [Ado Vabbe and modern art]. Sarapik, Virve et al. (eds.). Kunstiteaduslikke uurimusi, 7. Tallinn: Eesti Kunstiteadlaste Ühing, pp. 180-198. 
